\title{
Land cover models to predict non-point nutrient inputs for selected biomes in South Africa
}

\author{
AR Slaughter ${ }^{1 *}$ and SK Mantel ${ }^{1}$ \\ IInstitute for Water Research, Rhodes University, PO Box 94, Grahamstown, 6140, South Africa
}

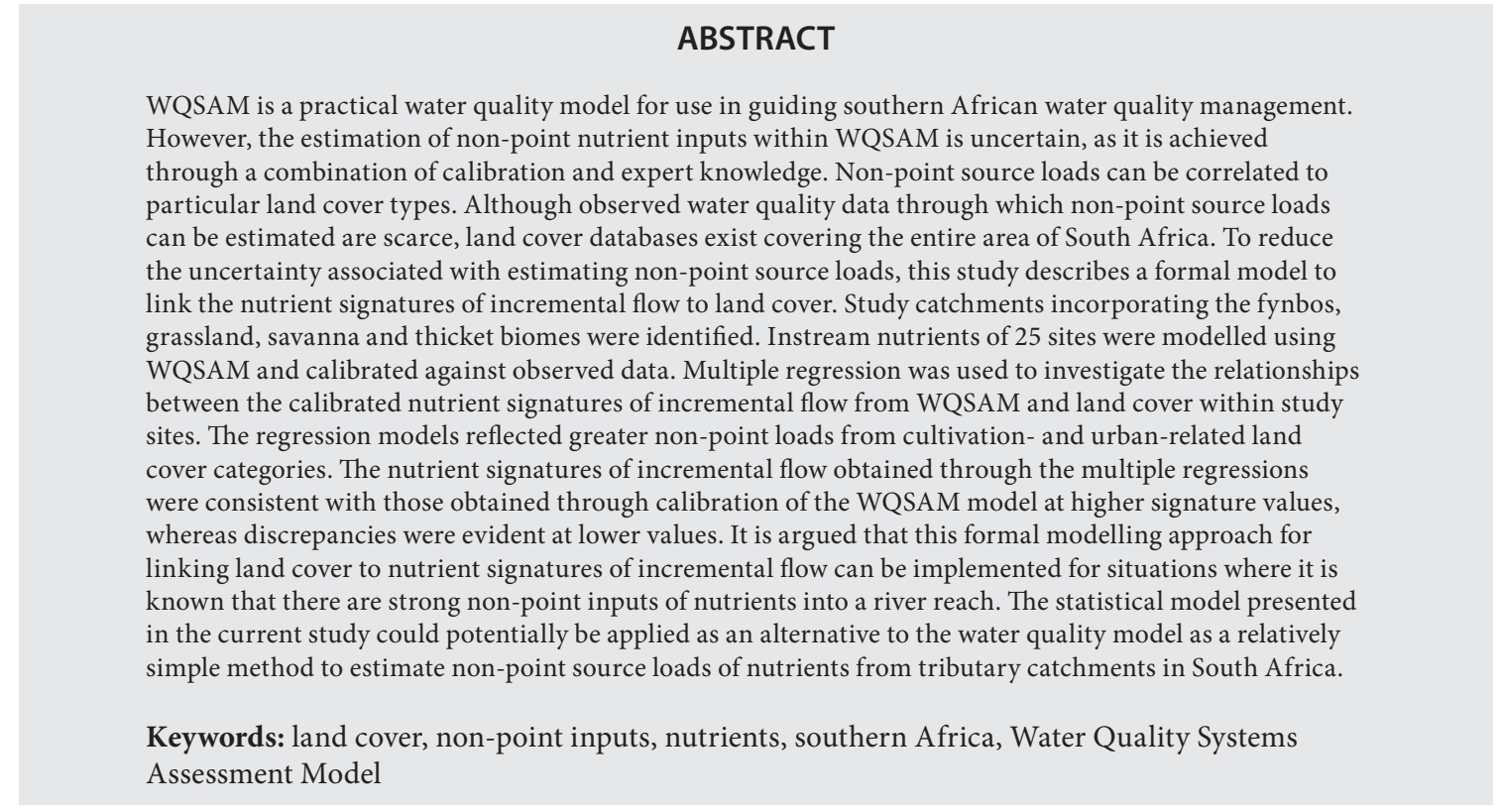

\section{INTRODUCTION}

The continual degradation of water quality of freshwater resources is a global problem (Zimmerman et al., 2008). Water quality models can assist in the management of water quality by facilitating an understanding of the processes affecting water quality, producing further water quality data over finer spatial and temporal scales to complement scarce observed data and allowing scenario analysis to explore the water quality consequences of different management actions.

Water quality modelling in South Africa is constrained by a lack of observed data, technical modelling expertise and funding, and although there is a rich history of hydrological modelling and systems modelling for flow (e.g. the Pitman and ACRU models: Pitman, 1973; Schulze, 1989), water quality research and modelling is relatively undeveloped. The application of existing internationally developed water quality models to South African catchments is hindered by the aforementioned constraints on observed data and modelling expertise. Within this context, the Water Quality Systems Assessment Model (WQSAM) (Hughes and Slaughter, 2016; Slaughter et al., 2015) was designed to use the available observed water quality data and to simulate water quality data that are useful for water resource management in South Africa, in that WQSAM takes as input, flow data generated by routinely used systems models, and water quality data are simulated in a form that is able to provide an estimate of risks associated with management decisions. WQSAM has initially focused on simulating nutrients, as eutrophication is arguably currently the most pressing water quality issue within freshwater resources in South Africa.

However, a common challenge within water quality modelling, both for simple models such as WQSAM and more complex models, is quantifying the loads of pollutants originating from non-point sources, as well as appropriately representing the temporal and spatial scales involved (Heathwaite, 2010). In the case of WQSAM, the contribution of non-point sources is modelled by setting water quality signatures, as concentration values, to surface and subsurface flows of incremental flow. These signature values are set mostly as a parameterisation exercise, guided by the predominant land cover within a catchment. However, since observed water quality data are typically scarce and are available only at coarse spatial and temporal scales, the aforementioned approach introduces a large amount of uncertainty into the water quality modelling exercise. Therefore, a more rigorous approach to quantifying water quality signatures of incremental flow fractions within WQSAM is required.

\footnotetext{
* To whom all correspondence should be addressed:

* 용 (046) 603 8532; e-mail: a.slaughter@ru.ac.za
}

Received 1 September 2016; accepted in revised form 3 July 2017 
There have been various previous attempts at quantifying non-point loads of pollutants in South Africa, including a WRC report by Dabrowski et al. (2013) and a report by the Department of Water Affairs (DWA, 2013), and some models have incorporated processes for estimating non-point source loads such as process-orientated catchment-scale models like SWAT (Arnold et al., 1998), which was used by Dabrowski (2014) to predict the trophic statuses of reservoirs in the Olifants catchment. In addition, Slaughter and Hughes (2013) developed a simple model to separate point and nonpoint loads of nutrients from historical monitoring data in South Africa. A common past approach is the use of export coefficients (unit area exports), and this approach has also been attempted in South Africa (Grobler and Silberbauer, 1985; Simpson and Stone, 1988; Pegram and Görgens, 2001). However, this approach is not ideal in the case of the present study in that export coefficients are usually applied over broad spatial and temporal scales, which would not find much use in parameterising a daily-time-step water quality model. This is because water quality is typically affected by transient events, such as rainfall-runoff events, and loading derived from the export coefficient approach would have insufficient temporal resolution to adequately parameterise a daily-time-step water quality model to account for non-point loads.

Bowes et al. (2010) explored the relationship between instream flow and total phosphorus concentration, and developed a model to separate a point and non-point load signature, thereby allowing the quantification of non-point loads into a river. Slaughter and Hughes (2013) used the conceptual understanding of the Bowes et al. (2010) model to develop a model appropriate for South African rivers, where inputs from point sources show high temporal variability. Slaughter and Mantel (2013) provide a simple method to relate land cover to non-point source inputs. The model by Slaughter and Mantel (2013) would be most appropriate to fulfil the requirements of the current research; however, their model relates instream non-point nutrient signatures to the land cover of the entire upstream catchment. Setting the values of the concentration signatures of the incremental flow fractions within the WQSAM model requires knowledge of the relationship between the water quality concentrations of incremental flow (flow from single tributaries rather than cumulative flow from several tributaries) from single subcatchments and land cover within those subcatchments.

The aim of the present study was to determine the relationship between land cover and water quality signatures of incremental flow within subcatchments, to reduce the uncertainty of modelling non-point load inputs of nutrients within the WQSAM model.

\section{METHODS AND STUDY AREAS}

\section{Regionalisation approach}

We investigated the relationships between non-point loads (represented as concentrations in $\mathrm{mg} \cdot \mathrm{L}^{-1}$ ) and land cover (land cover categories as fractions of the total area) within subcatchments, and since it can be assumed that broad regional characteristics will affect the relationships between land cover and non-point load inputs, these relationships should be investigated on a regional scale. To account for regional relationships, the spatial scale chosen within the present study was that of biomes, and in this respect, the categorisation of
Low and Rebelo (1996) was used. A biome can be broadly described as the naturally occurring community of flora and fauna occupying a particular habitat. Biomes are likely to be characterised by soil and vegetation type, both of which influence the water quality of runoff (non-point inputs). Therefore, we considered the biome categorisation of Low and Rebelo (1996) as suitable to account for regional effects on nonpoint water quality loads within the present study.

\section{Study catchments}

It is likely that the water quality of a point within a catchment receiving water from multiple tributaries will be affected by multiple water quality processes, including non-point loads, point source loads and instream processes, and it would be difficult to isolate the non-point source loads within such a situation. Therefore, tributary catchments receiving incremental flow were preferentially selected according to 4 requirements to reduce the effect of confounding variables:

1) The absence of large dams, as dams would introduce confounding water quality processes

2) The absence of large informal settlements, town or cities, to avoid high leverage from point source pollutants

3) Catchments consisting of at least two quaternary catchments, so that the available catchment area would generate sufficient rainfall-runoff for mobilisation of nonpoint source loads

4) Catchments for which there are an adequate amount of complete daily flow records as well as a reasonable amount of water quality data

These requirements yielded few suitable sites being identified, and the catchments selected represented 4 biomes. Table 1 lists the sites selected, whereas Fig. 1a-c shows the locations of the catchments according to biomes.

\section{Data}

A period of complete daily flow data was obtained for each study catchment, with periods ranging from 1 to 33 years (dates shown in Table 1), accessed from the South African Department of Water and Sanitation (DWS) Resource Quality Information Services (RQIS) website (DWS, 2015). Although it is recognised that the periods of data were short for some catchments, and that there is therefore a possibility of not being able to adequately recognise realistic water quality trends, very few suitable catchments could be identified, and therefore all available catchments were used. No discernible increasing or decreasing trends were evident in the water quality data. The DWS historical monitoring water quality data were accessed for the periods corresponding to flow for each site from the same aforementioned website. The present study focused on nutrients, concentrating specifically on nitrite plus nitrate nitrogen $\left(\mathrm{NO}_{2} \mathrm{~N}+\mathrm{NO}_{3} \mathrm{~N}\right)$, ammonium nitrogen $\left(\mathrm{NH}_{4} \mathrm{~N}\right)$ and phosphate phosphorus $\left(\mathrm{PO}_{4} \mathrm{P}\right)$, as these water quality variables can be strongly associated with non-point source loads, such as agriculture and urban areas, and these variables are important determinants of eutrophication. Land cover data were obtained from the South African National Land-Cover Dataset (NLC 2000; Van den Berg et al., 2008). If a particular monitoring point was not located at the catchment outlet, the catchment area was delineated for each water quality monitoring point by referring to 1:50 000 river and relief shapefiles in ArcMap 10.3 (ESRI, Inc.). The land cover spatial dataset was then clipped by 


\begin{tabular}{|l|l|l|l|l|}
\hline \multicolumn{5}{|c|}{ TABLE 1 } \\
\hline \multirow{2}{*}{ Properties of study areas chosen and availability of data } \\
\hline \multirow{2}{*}{ G1H010 } & $\begin{array}{l}\text { Quaternary } \\
\text { catchment }\end{array}$ & \multirow{2}{*}{ Biome } & \multicolumn{2}{|l|}{ Observed data } \\
\cline { 3 - 5 } & G10E & Fynbos & 1983 & 2003 \\
\hline G1H028 & G10G & Fynbos & 1982 & 2015 \\
\hline G1H034 & G10J & Fynbos & 1985 & 2007 \\
\hline G2H037 & G22F & Fynbos & 1991 & 2015 \\
\hline H2H008 & H20C & Fynbos & 1979 & 1995 \\
\hline J1H016 & J12A & Fynbos & 1979 & 2001 \\
\hline C2H005 & C22H/C22J & Grassland & 2001 & 2015 \\
\hline C5H007 & C52F & Grassland & 1988 & 2015 \\
\hline C5H056 & C52A & Grassland & 2002 & 2015 \\
\hline C8H006 & C81H & Grassland & 1977 & 1985 \\
\hline A2H032 & A22C & Savanna & 1979 & 2004 \\
\hline A2H034 & A21G & Savanna & 1971 & 2003 \\
\hline A6H010 & A61C & Savanna & 1999 & 2007 \\
\hline B1H018 & B11A & Savanna & 1993 & 1998 \\
\hline B4H009 & B41G & Savanna & 1980 & 1992 \\
\hline B9H002 & B90F & Savanna & 1991 & 2002 \\
\hline X2H012 & X21F & Savanna & 1986 & 2015 \\
\hline X3H003 & X31C & Savanna & 1979 & 2010 \\
\hline X3H015 & X33B & Savanna & 1995 & 1996 \\
\hline P3H001 & P30B & Thicket & 2002 & 2010 \\
\hline P4H001 & P40C & Thicket & 2000 & 2010 \\
\hline R2H009 & R20D & Thicket & 1971 & 1998 \\
\hline R2H012 & R20C & Thicket & 1971 & 1999 \\
\hline U8H001 & U80G & Thicket & 1992 & 2010 \\
\hline
\end{tabular}

${ }^{1}$ The observed data period is daily for flow and at a lower resolution for water quality, usually one a week or less.

(a)
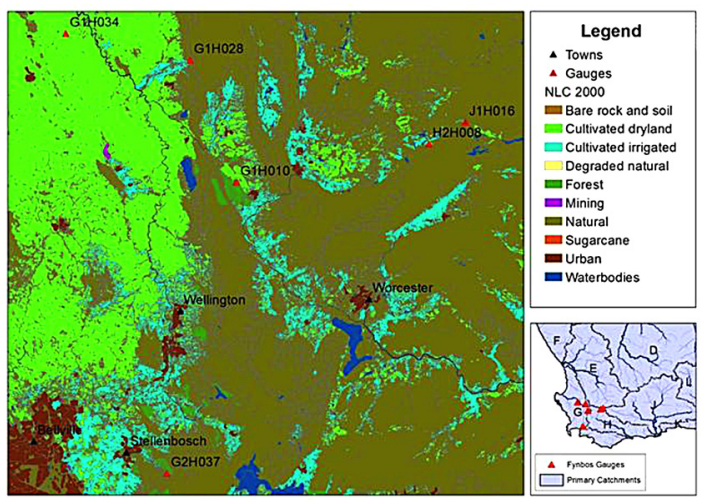

(c)

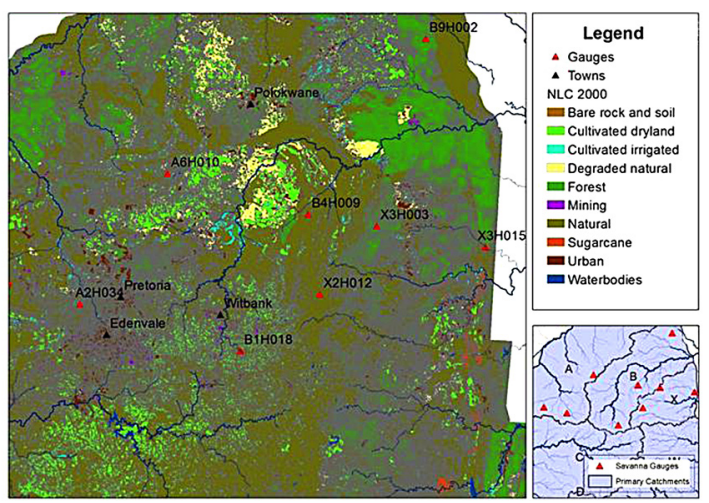

the monitoring point catchment and ArcMap 10.3 functions (calculate geometry, summarise) were used to calculate the total areas under each land cover class in the catchment. The original dataset contained 45 land cover classes which were combined into 10 categories for the present study (Table 2). This was done because the low number of suitable sites identified in combination with a large number of categories decreases the power or even excludes certain statistical analyses, such as multiple regression. In addition, working with so many categories within a water quality model would be a challenge, as each would require a dedicated parameter. The grouping of land cover categories was guided by a preliminary principle component analysis (PCA) (analysis not shown) to obtain a general indication of which land cover categories show similar patterns to water quality variables. In addition, land cover categories that were more similar were grouped together, such as the grouping of urban, rain-fed agriculture and irrigated agriculture categories. The present study investigated the relationship between land cover and non-point source loads considering all land cover within a catchment, and also land cover within a $100 \mathrm{~m}$ riparian zone, similar to the strategy adopted in previous studies that have assumed riparian zones to have a disproportionately large effect on water quality (e.g. Maillard and Santos, 2007; Rodriguez et al., 2007). The groupings of original land cover categories into the more general categories are listed below. The letter (A-J) of each land cover category will be used for the later presentation of results.

\section{Data validation/calibration}

Non-point source loads are simulated in WQSAM by assigning water quality concentrations to flow fractions of incremental flow, namely the surface (surface flow) and sub-surface flow (interflow and groundwater flow) fractions. (b)

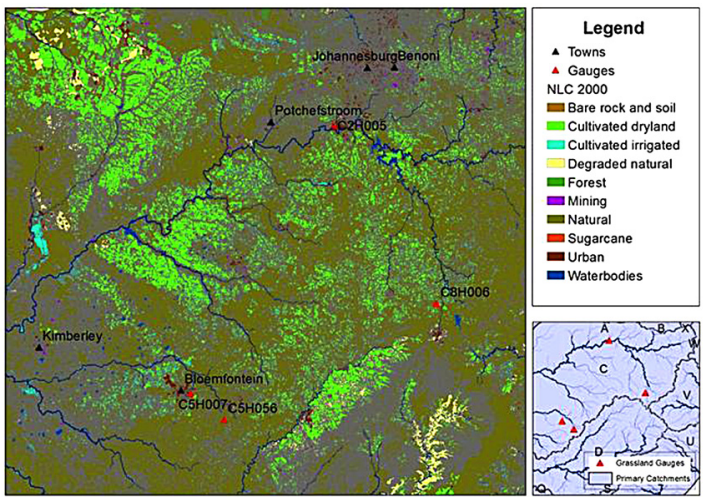

(d)

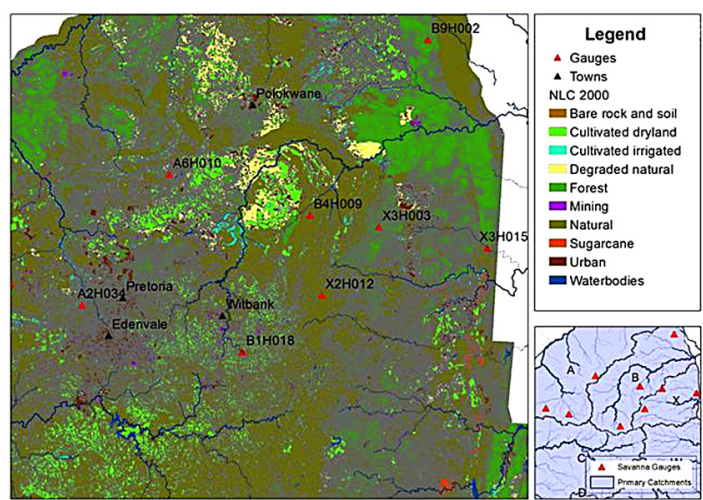

Figure 1

Location of study catchments within South Africa, representing 4 biomes: (1) fynbos; (2) grassland; (3) savanna; (4) thicket 


\begin{tabular}{|c|c|c|}
\hline \multicolumn{3}{|c|}{$\begin{array}{l}\text { TABLE } 2 \\
\text { Grouping of land cover categories from the South African National Land-Cover Dataset (NLC 2000; } \\
\text { Van den Berg et al., 2008) into more generic land cover categories for the purpose of the current study }\end{array}$} \\
\hline Code & Grouped land cover category & Original land cover classes \\
\hline A & Bare rock and soil & $\begin{array}{l}\text { Bare rock and soil (erosion: dongas/gullies); bare rock and soil (erosion: sheet); bare rock } \\
\text { and soil (natural). }\end{array}$ \\
\hline B & Cultivated dryland & $\begin{array}{l}\text { Cultivated, permanent, commercial, dryland; cultivated, temporary, commercial, } \\
\text { dryland; cultivated, temporary, subsistence, dryland }\end{array}$ \\
\hline C & Cultivated irrigated & $\begin{array}{l}\text { Cultivated, permanent, commercial, irrigated; cultivated, temporary, commercial, } \\
\text { irrigated; cultivated, temporary, subsistence, irrigated }\end{array}$ \\
\hline D & Sugarcane & Cultivated, permanent, commercial, sugarcane \\
\hline E & Natural & $\begin{array}{l}\text { Improved grassland; shrubland and low fynbos; thicket, bushland, bush clumps, } \\
\text { high fynbos; unimproved (natural) grassland }\end{array}$ \\
\hline $\mathbf{F}$ & Mining & $\begin{array}{l}\text { Mines \& quarries (mine tailings, waste dumps); mines \& quarries (surface- based } \\
\text { mining); mines \& quarries (underground/subsurface mining) }\end{array}$ \\
\hline G & Waterbodies & Waterbodies; wetlands \\
\hline $\mathrm{H}$ & Urban & $\begin{array}{l}\text { Urban/built-up (residential); urban / built-up (residential, formal suburbs); urban built-up } \\
\text { (residential, formal township); urban / built-up (residential, hostels); urban/built-up } \\
\text { (residential, informal squatter camp); urban/built-up (residential, informal township); } \\
\text { urban/built-up (rural cluster); urban/built-up (smallholdings, shrubland); urban/built-up, } \\
\text { (commercial, education, health, Information technology); urban/built-up, (commercial, } \\
\text { mercantile); urban / built-up (smallholdings, grassland);urban/built-up (smallholdings, } \\
\text { woodland); urban/built-up (smallholdings, thicket, bushland); urban/built-up, } \\
\text { (industrial/transport: heavy); urban/built-up, (industrial/transport: light). }\end{array}$ \\
\hline 1 & Degraded natural & $\begin{array}{l}\text { Degraded forest \& woodland; degraded thicket, bushland, etc.; degraded unimproved } \\
\text { (natural) grassland }\end{array}$ \\
\hline J & Forest & $\begin{array}{l}\text { Forest (indigenous); forest plantations (Acacia spp.); forest plantations (clearfelled); } \\
\text { forest plantations (Eucalyptus spp.); forest plantations (other/mixed spp.); forest } \\
\text { plantations (Pinus spp.); woodland (previously termed forest and woodland) }\end{array}$ \\
\hline
\end{tabular}

For the generation of non-point loads, the signatures of the surface, and to a lesser extent interflow fractions, would be relevant. A WQSAM setup was created for each study catchment. However, only limited aspects of the WQSAM model were applicable to the present study. The unbroken period of observed daily flow data for each catchment was used as flow data in WQSAM to drive water quality simulations. Only the baseflow separation part (Hughes et al., 2003) of the hydrological routines of WQSAM was applicable, as the daily observed flow did not require monthly to daily flow disaggregation using the method by Slaughter et al. (2015). The baseflow separation method separates incremental flow into 3 flow fractions: surface water flow, interflow and groundwater flow, and the method requires the setting of 2 parameter values. The approach taken in setting these parameter values was to assign the same reasonable default values (as determined through past research) to all the studied catchments. Although this could be regarded as a source of uncertainty within the present study, the determination of appropriate parameter values for baseflow separation is regarded as being particularly problematic in hydrological studies (see Kapangaziwiri et al., 2011) due to various reasons: the general lack of observed data with which to validate baseflow separation methods and parameter values, the range of baseflow separation methods available and the conflicting results they generate, the difficulties in distinguishing between the origins of surface water with regard to flow fractions, as well as the disparity in temporal scales at which the different flow fractions operate. Therefore, it was decided that determination of appropriate baseflow separation parameters would be beyond the scope of the present study. The default parameter values chosen, in relation to the Hughes et al. (2003) baseflow separation method, were:

$$
\alpha_{S F}=0.95 \text { and } \alpha_{B F}=0.92 \text {, }
$$

where: $\alpha_{\mathrm{SF}}$ relates to the alpha parameter used to separate surface flow from subsurface flow, and $\alpha_{B F}$ relates to the parameter used to separate interflow from groundwater flow within the subsurface flow. For both separations (surface flow and base flow), the $\beta$ parameter value was kept constant at 0.5, as recommended by Hughes et al. (2003). The full flow separation equation as well as the description of the separation parameters are available in Hughes et al. (2003)

In the present study, only the relationship between surface flow concentrations and land cover was investigated, as the relationships between land cover and the subsurface flow fractions are less certain and also operate at different spatial and temporal scales to surface water. A restricted water quality simulation part of WQSAM was employed, with only the parameters associated with the flow fraction nutrient signatures changed, so as to obtain water quality simulations that were calibrated against the observed water quality data:

$$
Q_{N}=\frac{\frac{\left(S F_{N} \times S F\right)}{1000}+\frac{\left(I F_{N} \times I F\right)}{1000}+\frac{\left(G W_{N} \times G W\right)}{1000} \times 1000}{Q},
$$

where: $Q_{N}$ is the instream nutrient concentration $\left(\mathrm{mg} \mathrm{L}^{-1}\right), S F_{N}$ is the surface flow nutrient concentration $\left(\mathrm{mg} \cdot \mathrm{L}^{-1}\right), S F$ is the surface flow $\left(\mathrm{m}^{3} \cdot \mathrm{s}^{-1}\right), I F_{N}$ is the interflow nutrient concentration $\left(\mathrm{mg} \cdot \mathrm{L}^{-1}\right), I F$ is the interflow $\left(\mathrm{m}^{3} \cdot \mathrm{s}^{-1}\right), G W_{N}$ is the groundwater flow nutrient concentration (mg. $\left.\mathrm{L}^{-1}\right), G W$ is the groundwater 
flow $\left(\mathrm{m}^{3} \cdot \mathrm{s}^{-1}\right)$ and $Q$ is the total instream flow $\left(\mathrm{m}^{3} \cdot \mathrm{s}^{-1}\right)$. In WQSAM, the setting of the different flow signatures is primarily a calibration exercise, as highly temporally variable water quality measures in the observed data can be represented in the simulated data by adjusting $S F_{N}$, whereas more stable water quality measures in the observed data can be represented by the simulated data by adjusting $I F_{N}$ and $G W_{N}$.

Once calibration against observed data was completed, the water quality signatures applied to the surface water flow fraction of each catchment $\left(S F_{N}\right)$ were collated for further analyses.

\section{Multiple regression model development}

Multiple regression was employed to investigate the relationships between surface flow water quality signatures $\left(S F_{N}\right)$ and land cover. The land cover coverage within each catchment was explored in terms of the proportion of land cover types within the total area of the catchment. The riparian zone has been found to have marked effects on non-point source inputs of water quality loads (e.g. Anbumozhi et al., 2005). To account for the effects of scale, the analyses were repeated for the land cover types of the $100 \mathrm{~m}$ riparian zone, which is within the width of the riparian zone used in similar studies, such as by Maillard and Santos (2007). The current study focused on only one riparian buffer strip width as a preliminary study. Regression models implemented in Statistica V13 (Dell Inc.) did not provide adequate goodness-of-fit statistics (data not shown). The multiple regression analyses were therefore conducted in Excel, using a regression equation with the general form of:

$$
\begin{aligned}
S F_{N}= & \left(A \cdot x_{1}\right)+\left(B \cdot x_{2}\right)+\left(C \cdot x_{3}\right)+\left(D \cdot x_{4}\right)+\left(E \cdot x_{5}\right)+ \\
& \left(F \cdot x_{6}\right)+\left(G \cdot x_{7}\right)+\left(H \cdot x_{8}\right)+\left(I \cdot x_{9}\right)+\left(J \cdot x_{10}\right),
\end{aligned}
$$

where: $A-J$ represent the land cover categories mentioned earlier, as fractions of the total area, and $x_{1}-x_{10}$ represent the regression parameters calibrated through Solver applied to respective land cover categories. The Chi-square statistic was used as a goodness-of-fit statistic for each regression. Solver was implemented to identify the best values for the parameters $x_{1}-x_{10}$ by finding the minimum value for the sum of Chisquare. Values of $x_{1}-x_{10}$ were constrained to be $\geq 0$, with the assumption that none of the land cover categories would act as nutrient sinks.

\section{RESULTS}

The results of the model calibration to observed water quality

\begin{tabular}{|c|c|c|c|c|c|c|c|c|c|c|c|c|c|}
\hline & $\begin{array}{r}\text { Surfa } \\
\text { of the } \\
\mathrm{N}\end{array}$ & $\begin{array}{l}\text { ce, interfl } \\
\text { Water Qu } \\
\text { sh-Sutcli }\end{array}$ & $\begin{array}{l}\text { ow and gro } \\
\text { sality Syste } \\
\text { ffe efficien }\end{array}$ & $\begin{array}{l}\text { undwater } \\
\text { ms Assess } \\
\text { cies (NSE) }\end{array}$ & 列 & $\begin{array}{l}\text { TABLE } \\
\text { water qua } \\
\text { Model (W } \\
\text { easure of }\end{array}$ & $\begin{array}{l}3 \\
\text { ality signatu } \\
\text { (QSAM) to } \\
\text { goodness }\end{array}$ & $\begin{array}{l}\text { ures obtai } \\
\text { historical } \\
\text { of fit for e }\end{array}$ & ach si & $\begin{array}{l}\text { hrough ca } \\
\text { tions, as } \\
\text { te and nu }\end{array}$ & $\begin{array}{l}\text { libration } \\
\text { vell as the } \\
\text { itrient }\end{array}$ & & \\
\hline & & & $\mathrm{O}_{2} \mathrm{~N}+\mathrm{NO}_{3} \mathrm{~N}$ & $\sqrt{ }\left(\mathrm{mg} \cdot \mathrm{L}^{-1}\right)$ & & & $\mathrm{NH}_{4} \mathrm{~N}(\mathrm{mc}$ & $\left.g \cdot L^{-1}\right)$ & & & $\mathrm{PO}_{4} \mathrm{P}(\mathrm{mc}$ & $\left.g \cdot L^{-1}\right)$ & \\
\hline Site & Biome & Surface & Interflow & GW flow & NSE & Surface & Interflow & GW flow & NSE & Surface & Interflow & GW flow & NSE \\
\hline G1H010 & Fynbos & 1.6 & 0.1 & 0 & 0.64 & 0.1 & 0.05 & 0 & 0.78 & 0.07 & 0.01 & 0.01 & 0.88 \\
\hline G1H028 & Fynbos & 0.05 & 0.01 & 0.02 & 0.84 & 0.06 & 0.03 & 0.01 & 0.27 & 0.03 & 0.01 & 0 & 0.28 \\
\hline G1H034 & Fynbos & 5 & 0.03 & 0.05 & 0.48 & 0.3 & 0.1 & 0.1 & 0.27 & 0.5 & 0.05 & 0 & 0.61 \\
\hline G2H037 & Fynbos & 0.07 & 0.03 & 0.02 & 0.32 & 0.07 & 0.02 & 0.02 & 0.87 & 0.05 & 0 & 0 & 0.26 \\
\hline $\mathrm{H} 2 \mathrm{H} 008$ & Fynbos & 0.1 & 0.02 & 0.01 & 0.39 & 0.07 & 0.02 & 0.02 & 0.78 & 0.02 & 0.001 & 0 & 0.49 \\
\hline J1H016 & Fynbos & 0.1 & 0 & 0.02 & 0.41 & 0.15 & 0.01 & 0.01 & 0.93 & 0.05 & 0.1 & 0 & 0.90 \\
\hline C2H005 & Grassland & 10 & 3 & 3 & 0.78 & 5 & 0.7 & 0 & 0.63 & 5 & 2 & 0.1 & 0.81 \\
\hline $\mathrm{C} 5 \mathrm{H} 007$ & Grassland & 40 & 30 & 0.5 & 0.95 & 5 & 0.5 & 0.1 & 0.41 & 15 & 10 & 0.2 & 0.91 \\
\hline C5H056 & Grassland & 0.5 & 0.1 & 0 & 0.98 & 0.4 & 0.1 & 0 & 0.57 & 0.5 & 0 & 0 & 0.63 \\
\hline $\mathrm{C} 8 \mathrm{H} 006$ & Grassland & 0.3 & 0.1 & 0 & 0.99 & 0.2 & 0.05 & 0 & 0.63 & 0.1 & 0 & 0 & 0.65 \\
\hline A2H032 & Savanna & 1 & 0.5 & 0.1 & 0.43 & 0.2 & 0.05 & 0 & 0.34 & 0.2 & 0.05 & 0 & 0.21 \\
\hline A2H034 & Savanna & 3 & 1 & 0.5 & 0.95 & 0.3 & 0 & 0 & 0.39 & 0.3 & 0.01 & 0 & 0.68 \\
\hline A6H010 & Savanna & 12 & 5 & 0 & 0.97 & 0.3 & 0 & 0 & 0.35 & 0.1 & 0 & 0 & 0.56 \\
\hline B1H018 & Savanna & 0.2 & 0.05 & 0.03 & 0.65 & 0.07 & 0.04 & 0.02 & 0.54 & 0.07 & 0.05 & 0.01 & 0.79 \\
\hline B4H009 & Savanna & 0.45 & 0.06 & 0.02 & 0.97 & 0.1 & 0.01 & 0.01 & 0.94 & 0.05 & 0 & 0 & 0.96 \\
\hline B9H002 & Savanna & 9 & 0.1 & 0 & 0.25 & 0.1 & 0.04 & 0.02 & 0.72 & 0.1 & 0.03 & 0.01 & 0.43 \\
\hline $\mathrm{X} 2 \mathrm{H} 012$ & Savanna & 2 & 0.5 & 0 & 0.92 & 0.5 & 0 & 0 & 0.70 & 0.4 & 0.01 & 0.02 & 0.99 \\
\hline $\mathrm{X} 3 \mathrm{H} 003$ & Savanna & 1.3 & 0.7 & 0.2 & 0.95 & 1 & 0 & 0 & 0.91 & 0.2 & 0 & 0 & 0.66 \\
\hline $\mathrm{X} 3 \mathrm{H} 015$ & Savanna & 0.5 & 0 & 0.04 & 0.97 & 0.2 & 0 & 0.02 & 0.94 & 0.06 & 0.04 & 0.01 & 0.94 \\
\hline P3H001 & Thicket & 7 & 0.5 & 0.05 & 0.58 & 0.4 & 0 & 0 & 0.64 & 0.1 & 0 & 0 & 0.24 \\
\hline P4H001 & Thicket & 1.5 & 0.1 & 0.03 & 0.52 & 0.2 & 0.03 & 0.02 & 0.95 & 0.5 & 0 & 0 & 0.23 \\
\hline R2H009 & Thicket & 1.5 & 0.1 & 0 & 0.53 & 0.15 & 0.05 & 0.02 & 0.68 & 0.1 & 0.05 & 0 & 0.31 \\
\hline R2H012 & Thicket & 1.7 & 0.3 & 0.02 & 0.85 & 0.3 & 0.02 & 0 & 0.79 & 0.1 & 0.01 & 0 & 0.39 \\
\hline U8H001 & Thicket & 1.6 & 0.7 & 0 & 0.65 & 0.07 & 0 & 0.02 & 0.95 & 0.1 & 0 & 0 & 0.89 \\
\hline
\end{tabular}
data in WQSAM are presented first, after which the results of 
the multiple regression to quantify relationships between the model parameter values and land cover are presented.

\section{Model frequency distribution calibration}

Table 3 shows the surface, interflow and groundwater flow water quality signatures obtained through the calibration of WQSAM to observed historical water quality data. Also shown are the Nash-Sutcliffe efficiencies (NSEs) (Nash and Sutcliffe, 1970) for each calibration, as a measure of goodness of fit. Importantly, the comparisons of observed to simulated data were performed as frequency distributions, as WQSAM does not aim to accurately represent observed data as a daily times series, but rather to represent the frequency distribution of observed data, as simulations in the form of a frequency distribution can provide indications of risk associated with the exceedance of particular water quality thresholds.

For the fynbos biome $(n=6)$, the efficiency values obtained for $\mathrm{NO}_{2} \mathrm{~N}+\mathrm{NO}_{3} \mathrm{~N}$ ranged from 0.32 to 0.84 . The simulations of $\mathrm{NH}_{4}-\mathrm{N}$ obtained efficiency values ranging from 0.27 to 0.93 , whereas the simulations of $\mathrm{PO}_{4} \mathrm{P}$ showed efficiency values ranging from 0.26 to 0.90 .

For the grassland biome $(n=4)$, the efficiency values obtained for $\mathrm{NO}_{2} \mathrm{~N}+\mathrm{NO}_{3} \mathrm{~N}$ ranged from 0.78 to 0.99 . The simulations of $\mathrm{NH}_{4} \mathrm{~N}$ obtained efficiency values ranging from 0.41 to 0.63 . The simulations of $\mathrm{PO}_{4} \mathrm{P}$ obtained efficiency values ranging from 0.63 to 0.91 .

The efficiency values obtained for the savanna biome $(n=9)$ for $\mathrm{NO}_{2} \mathrm{~N}+\mathrm{NO}_{3} \mathrm{~N}$ ranged from 0.25 to 0.97 . The simulations of $\mathrm{NH}_{4} \mathrm{~N}$ obtained efficiencies ranging from 0.35 to 0.94 . The simulations of $\mathrm{PO}_{4} \mathrm{P}$ obtained efficiency values ranging from 0.43 to 0.99 .

For the thicket biome $(n=5)$, the efficiency values obtained for $\mathrm{NO}_{2} \mathrm{~N}+\mathrm{NO}_{3} \mathrm{~N}$ ranged from 0.52 to 0.85 . The simulations of $\mathrm{NH}_{4} \mathrm{~N}$ obtained efficiency values ranging from 0.64 to 0.95 . The range of efficiency values obtained for the simulations of $\mathrm{PO}_{4} \mathrm{P}$ was 0.24 to 0.89 .

\section{Results of multiple regression in Excel}

Table 4 shows the results of the multiple regression within Excel using Solver, showing the values of $x_{1}-x_{10}$ for each biome for the full catchment, as well as for the $100 \mathrm{~m}$ riparian zone. To validate the results of the multiple regression, the values of $S F_{N}$ through the multiple regressions were compared with those obtained through the WQSAM calibration to observed data. Figure 2 shows the $S F_{N}$ values obtained through the WQSAM calibration to observed data on the $\mathrm{X}$-axis against the percentage error $\left(\%\right.$ error $=$ (regression $S F_{N}-$ model $\left.S F_{N}\right) /$ model $S F_{N}$ ) of the corresponding $S F_{N}$ values obtained through the multiple regression using land cover on the Y-axis. Generally, the high calibrated WQSAM $S F_{N}$ values corresponded well with the $S F_{N}$ values obtained through the multiple regression, whereas the lower calibrated WQSAM $S F_{N}$ values did not correspond particularly well with the $S F_{N}$ values obtained through the multiple regression. For example, for $\mathrm{NO}_{3} \mathrm{~N}+\mathrm{NO}_{2} \mathrm{~N}$ (Fig. 2a), the highest percentage error was approaching $3000 \%$ at a very low calibrated WQSAM $S F_{N}$ value. Also evident is that generally lower percentage errors were associated with the riparian zone multiple regression estimates of $S F_{N}$.

To estimate what these discrepancies mean in terms of actual water quality modelling, the values of $S F_{N}$ obtained through the multiple regression using the riparian zone land (a)
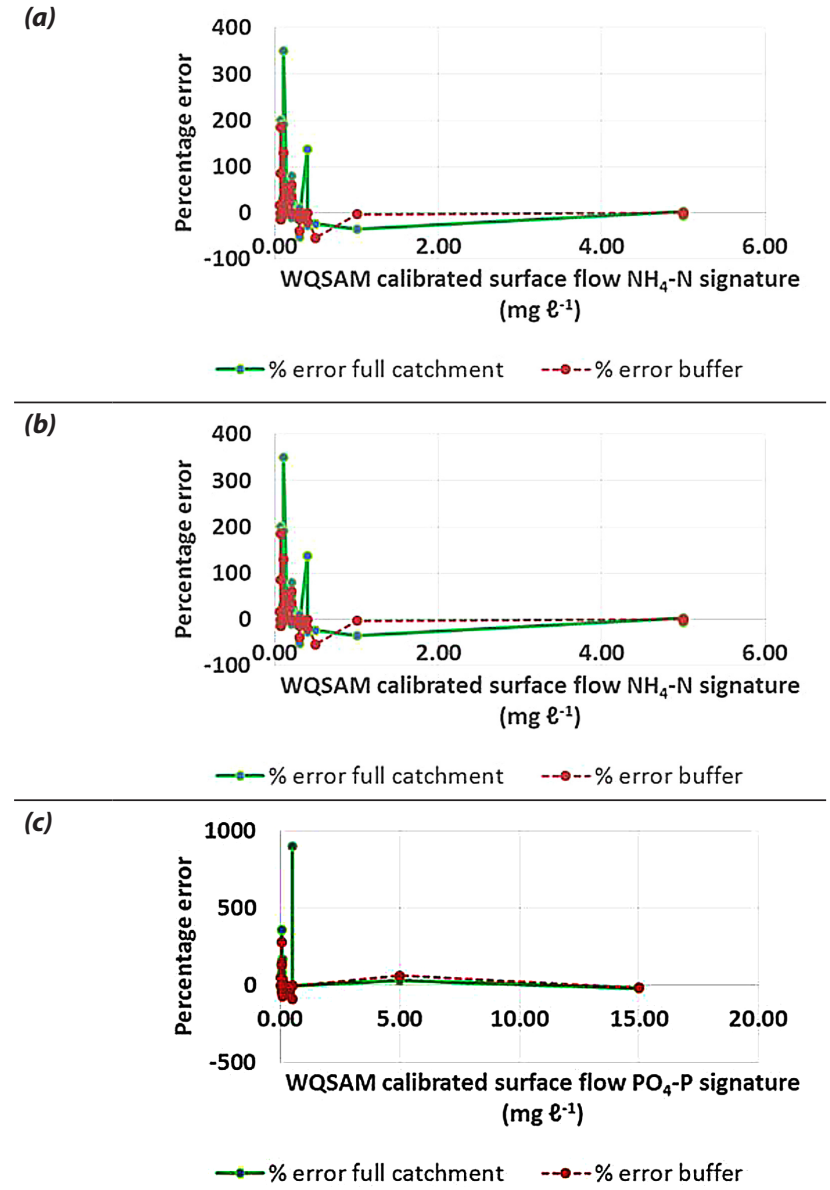

Figure 2

Graphs showing the relationship between the calibrated Water Quality System Assessment Model (WQSAM) parameters for the surface flow signature of: (a) $\mathrm{NO}_{3}-\mathrm{N}+\mathrm{NO}_{2}-\mathrm{N}$; (b) $\mathrm{NH}_{4}-\mathrm{N}$ and; (c) $\mathrm{PO}_{4}-\mathrm{P}$ for all biomes and sites (on the $x$-axis), and the corresponding values derived from multiple regression in Excel using land cover, shown as percentage error. Both the full catchment land cover and riparian zone $(100 \mathrm{~m})$ land cover relationships are shown.

cover, and associated with the highest percentage errors, were input into the WQSAM model setups for the respective catchments, and the model outputs were compared to the model outputs that were calibrated to observed data. For $\mathrm{NO}_{3} \mathrm{~N}+\mathrm{NO}_{2} \mathrm{~N}$, this was the $\mathrm{C} 5 \mathrm{H} 056$ grassland catchment (located in Free State Province) where the percentage error was $1248 \%$, for $\mathrm{NH}_{4} \mathrm{~N}$, this was the B1H018 catchment where the percentage error was $185 \%$, and for $\mathrm{PO}_{4} \mathrm{P}$ this was the $\mathrm{B} 4 \mathrm{H} 009$ savanna catchment where the percentage error was $280 \%$.

The results, shown as frequency distributions, are shown in Fig. 3. Although the discrepancies for $\mathrm{NH}_{4} \mathrm{~N}$ and $\mathrm{PO}_{4} \mathrm{P}$ are not as pronounced as the range of concentrations are rather low $\left(<0.2 \mathrm{mg} \cdot \mathrm{L}^{-1}\right.$ for both $\mathrm{NH}_{4} \mathrm{~N}$ and $\left.\mathrm{PO}_{4} \mathrm{P}\right)$, the discrepancy for $\mathrm{NO}_{3} \mathrm{~N}+\mathrm{NO}_{2} \mathrm{~N}$ for the two simulations is considerable, with a seven-fold discrepancy between the highest simulation of $\mathrm{NO}_{3} \mathrm{~N}+\mathrm{NO}_{2} \mathrm{~N}$ generated by the WQSAM model using the multiple regression estimate of $S F_{N}$, and the highest simulation of $\mathrm{NO}_{3} \mathrm{~N}+\mathrm{NO}_{2} \mathrm{~N}$ generated by the WQSAM model calibrated against observed data.

In addition, the $S F_{N}$ values generated through the multiple regressions for the catchments with the highest $S F_{N}$ 

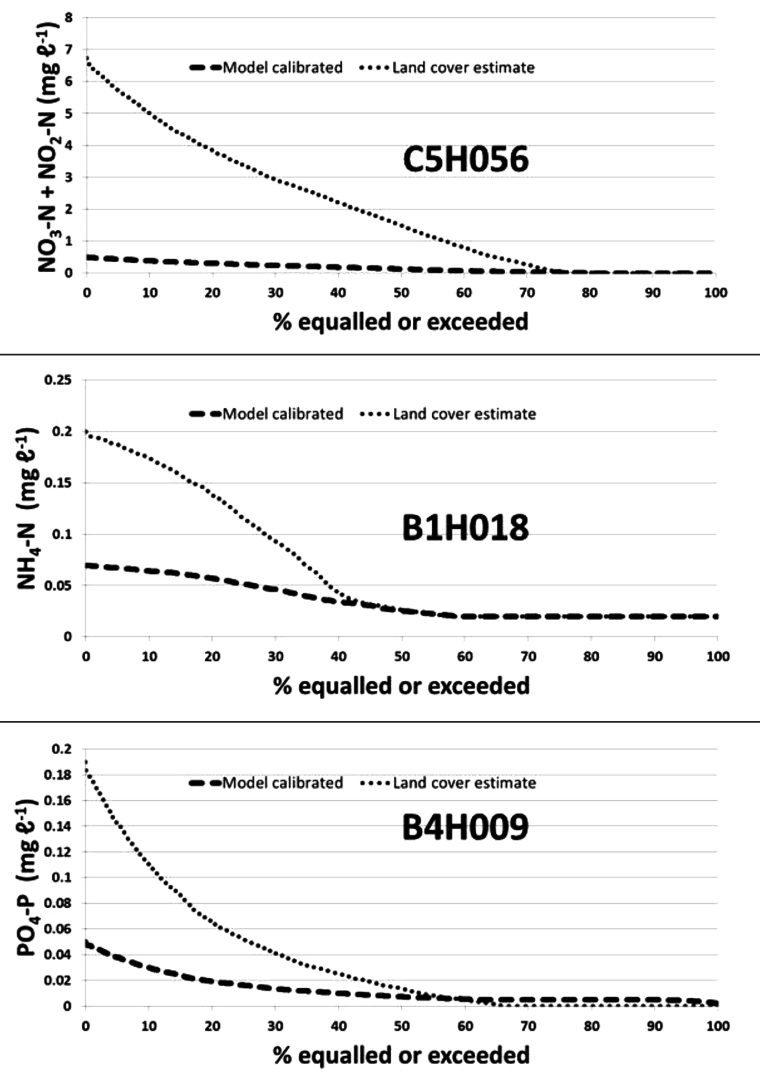

Figure 3

The values of surface flow nutrient concentrations $\left(S F_{N}\right)$, as estimated through multiple regression, and showing the greatest discrepancies with the corresponding $S F_{N}$ estimated by calibration of the Water Quality Systems Assessment Model (WQSAM) to observed data, were used as input into WQSAM setups for respective study catchments. Shown are the simulations by WQSAM for the calibration against observed data, as well as the simulation obtained when the $S_{N}$ value obtained through multiple regression was used as the parameter value instead. The comparisons are shown as frequency distributions.

values as estimated by calibration of the WQSAM model against observed data were identified. These were $\mathrm{C} 5 \mathrm{H} 007$ for $\mathrm{NO}_{3} \mathrm{~N}+\mathrm{NO}_{2} \mathrm{~N}, \mathrm{C} 5 \mathrm{H} 007$ for $\mathrm{PO}_{4} \mathrm{P}$ and $\mathrm{C} 2 \mathrm{H} 005$ for $\mathrm{NH}^{4} \mathrm{~N}$, with discrepancies between the $S F_{N}$ generated through model calibration and multiple regression of $-9.2 \%,-13.6 \%$ and $0 \%$, respectively. Similar to the above analysis, the $S F_{N}$ values were input into WQSAM and the model simulations were compared to the simulations obtained through the calibrated models. Since there was a $0 \%$ discrepancy between $S F_{N}$ values for $\mathrm{C} 2 \mathrm{H} 005$, this catchment was not investigated. As can be seen in Fig. 4, the differences between the model simulations using the two sources of $S F_{N}$ are minimal.

\section{DISCUSSION}

\section{Results of calibrations in WQSAM}

The WQSAM calibrations against observed data were generally sufficiently representative of the observed data (average NSE values of $0.71,0.67$ and 0.61 for $\mathrm{NO}_{2} \mathrm{~N}+\mathrm{NO}_{3} \mathrm{~N}, \mathrm{NH}_{4} \mathrm{~N}$ and $\mathrm{PO}_{4} \mathrm{P}$, respectively) to justify the use of the calibration estimates of $S F_{N}$ in the subsequent statistical analyses.
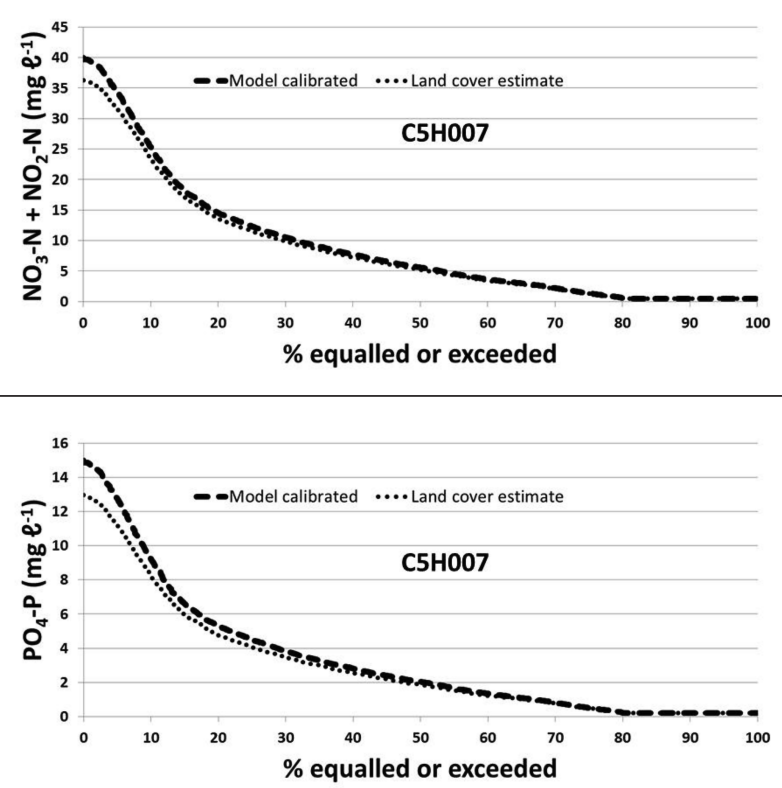

Figure 4

The values of surface flow nutrient concentrations $\left(S_{N}\right)$ as estimated through multiple regression, and showing the highest corresponding

$S F_{N}$ values estimated by calibration of the Water Quality Systems Assessment Model (WQSAM) to observed data, were used as input into the WQSAM model setups for respective study catchments. Shown are the simulations by WQSAM for the calibration against observed data, as well as the simulation obtained when the $S F_{N}$ value obtained through multiple regression was used as the parameter value instead. The comparisons are shown as frequency distributions. No comparison for $\mathrm{NH}_{4}-\mathrm{N}$ is shown as there was a $0 \%$ discrepancy between the $\mathrm{SF}_{N}$ values.

Within the fynbos biome, it is likely that agricultural activities or forestry influenced the water quality signatures of various sites, for example, land cover in G1H034 and G1H010 showed $94 \%$ cultivated dryland and $99 \%$ forestry, respectively.

Within the grassland biome, high spikes of all three nutrients were evident at Sites C5H007 and C2H005, the catchments of which were revealed to contain various categories of land cover that could potentially influence water quality, including $13 \%$ cultivated dryland, $1.2 \%$ cultivated irrigated and $1 \%$ urban for $\mathrm{C} 5 \mathrm{H} 007$, and $25 \%$ cultivated dryland, $2 \%$ mining and $14 \%$ urban for $\mathrm{C} 2 \mathrm{H} 005$. The nutrient signatures for $\mathrm{C} 5 \mathrm{H} 007$ were relatively higher than that of $\mathrm{C} 2 \mathrm{H} 005$, indicating perhaps that irrigated agriculture has a disproportionately large effect on water quality in comparison to other land cover types. This would make sense, as whereas other cultivation categories would mainly contribute to non-point loads during rainfall events, the non-point load contribution by irrigated agriculture would depend on the irrigation schedule as well as rainfall.

Within the savanna biome, the $\mathrm{A} 6 \mathrm{H} 010$ and $\mathrm{B} 9 \mathrm{H} 002$ sites showed relatively high concentrations of $\mathrm{NO}_{2}-\mathrm{N}+\mathrm{NO}_{3}$ $\mathrm{N}$. Although there is a mix of land cover categories within these two sites that could contribute to non-point sources of nutrients, such as cultivated dryland, cultivated irrigated and urban areas, the large proportions of forestry at the two sites (40\% for $\mathrm{A} 6 \mathrm{H} 010$ and $60 \%$ for $\mathrm{B} 9 \mathrm{H} 002$ ), as well as the fact that it is predominantly the $\mathrm{NO}_{2} \mathrm{~N}+\mathrm{NO}_{3} \mathrm{~N}$ nutrient species showing excess concentrations, indicates that perhaps forestry has the greatest influence on water quality for this biome. 


\begin{tabular}{|c|c|c|c|c|c|c|}
\hline \multicolumn{7}{|c|}{$\begin{array}{l}\text { TABLE } 4 \\
\text { Parameter values for the multiple regression equation (see Eq. 1) obtained using Solver in Excel }\end{array}$} \\
\hline & \multicolumn{2}{|c|}{$\mathrm{NO}_{2} \mathrm{~N}+\mathrm{NO}_{3} \mathrm{~N}$} & \multicolumn{2}{|c|}{$\mathrm{NH}_{4} \mathrm{~N}$} & \multicolumn{2}{|c|}{$\mathrm{PO}_{4} \mathrm{P}$} \\
\hline Parameter & Full & Riparian & Full & Riparian & Full & Riparian \\
\hline \multicolumn{7}{|c|}{ Fynbos biome } \\
\hline$x_{1}$ & 0.00 & 0.00 & 0.00 & 0.00 & 0.00 & 0.00 \\
\hline$x_{2}$ & 4.74 & 1.72 & 0.28 & 0.16 & 0.00 & 0.00 \\
\hline$x_{3}$ & 0.00 & 0.00 & 2.30 & 0.38 & 0.45 & 0.00 \\
\hline$x_{4}$ & 0.00 & 0.00 & 0.00 & 0.00 & 0.00 & 0.00 \\
\hline$x_{5}$ & 0.02 & 0.02 & 0.06 & 0.06 & 0.03 & 0.03 \\
\hline$x_{6}$ & 0.00 & 0.00 & 0.00 & 0.00 & 0.00 & 0.00 \\
\hline$x_{7}$ & 0.00 & 0.00 & 1.20 & 0.90 & 0.61 & 0.63 \\
\hline$x_{8}$ & 17.25 & 30.79 & 0.96 & 1.45 & 13.92 & 4.24 \\
\hline$x_{9}$ & 0.00 & 0.00 & 0.00 & 0.00 & 0.00 & 0.00 \\
\hline$x_{10}$ & 1.62 & 1.60 & 0.10 & 0.10 & 0.07 & 0.07 \\
\hline \multicolumn{7}{|c|}{ Grassland biome } \\
\hline$x_{1}$ & 0.00 & 0.00 & 0.00 & 0.00 & 0.00 & 0.28 \\
\hline$x_{2}$ & 0.00 & 0.00 & 0.00 & 9.69 & 0.00 & 0.00 \\
\hline$x_{3}$ & 2060.07 & 0.00 & 107.86 & 0.00 & 733.15 & 0.00 \\
\hline$x_{4}$ & 0.00 & 0.00 & 0.00 & 0.00 & 0.00 & 0.00 \\
\hline$x_{5}$ & 0.00 & 0.00 & 0.00 & 0.00 & 0.00 & 0.03 \\
\hline$x_{6}$ & 0.00 & 0.00 & 0.00 & 0.00 & 0.00 & 0.00 \\
\hline$x_{7}$ & 0.00 & 0.00 & 0.00 & 1.11 & 0.00 & 0.00 \\
\hline$x_{8}$ & 89.99 & 498.14 & 37.02 & 102.48 & 41.89 & 266.91 \\
\hline$x_{9}$ & 0.00 & 69.36 & 0.00 & 0.00 & 0.00 & 0.00 \\
\hline$x_{10}$ & 0.00 & 2901.19 & 0.00 & 0.00 & 0.00 & 16.49 \\
\hline \multicolumn{7}{|c|}{ Savanna biome } \\
\hline$x_{1}$ & 0.00 & 0.00 & 0.00 & 0.00 & 0.00 & 0.00 \\
\hline$x_{2}$ & 0.00 & 0.00 & 0.00 & 0.00 & 0.00 & 0.00 \\
\hline$x_{3}$ & 0.00 & 48.09 & 0.00 & 1.55 & 0.00 & 1.13 \\
\hline$x_{4}$ & 0.00 & 0.00 & 0.00 & 0.00 & 0.00 & 0.00 \\
\hline$x_{5}$ & 1.42 & 0.07 & 0.09 & 0.23 & 0.21 & 0.20 \\
\hline$x_{6}$ & 0.51 & 0.00 & 69.62 & 0.00 & 9.73 & 0.00 \\
\hline$x_{7}$ & 0.00 & 2.38 & 0.00 & 0.00 & 0.00 & 0.00 \\
\hline$x_{8}$ & 0.00 & 3.46 & 0.00 & 6.22 & 0.00 & 0.94 \\
\hline$x_{9}$ & 71.21 & 74.86 & 0.00 & 0.00 & 0.00 & 0.00 \\
\hline$x_{10}$ & 0.00 & 0.00 & 0.75 & 0.04 & 0.13 & 0.00 \\
\hline \multicolumn{7}{|c|}{ Thicket biome } \\
\hline$x_{1}$ & 0.00 & 0.00 & 0.00 & 0.00 & 0.00 & 0.37 \\
\hline$x_{2}$ & 0.00 & 0.00 & 0.00 & 0.00 & 0.07 & 0.20 \\
\hline$x_{3}$ & 0.00 & 0.00 & 0.00 & 1.29 & 28.68 & 7.87 \\
\hline$x_{4}$ & 0.00 & 0.00 & 0.00 & 0.00 & 0.35 & 0.11 \\
\hline$x_{5}$ & 2.88 & 0.29 & 0.29 & 0.04 & 0.00 & 0.09 \\
\hline$x_{6}$ & 0.00 & 0.00 & 0.00 & 0.00 & 0.00 & 0.00 \\
\hline$x_{7}$ & 710.86 & 1.34 & 1.34 & 9.38 & 0.00 & 0.00 \\
\hline$x_{8}$ & 0.00 & 1.45 & 1.45 & 6.61 & 0.70 & 19.56 \\
\hline$x_{9}$ & 0.00 & 0.00 & 0.00 & 0.00 & 0.06 & 0.00 \\
\hline$x_{10}$ & 0.40 & 0.00 & 0.00 & 0.56 & 0.00 & 0.12 \\
\hline
\end{tabular}


For the thicket biome, particularly high concentrations of $\mathrm{NO}_{2} \mathrm{~N}+\mathrm{NO}_{3} \mathrm{~N}$ are evident within the $\mathrm{P} 3 \mathrm{H} 001$ catchment. The reason for the elevated nutrient concentrations are not immediately evident, as the land cover for this site includes only a small area of agriculture (approx. 3\%), and predominantly natural area (96\%).

\section{Results of multiple regression in Excel}

Across all the biomes, the major land cover categories affecting water quality in terms of $\mathrm{NO}_{2} \mathrm{~N}+\mathrm{NO}_{3} \mathrm{~N}$ were found to include the cultivation categories, dryland, forest, natural areas and degraded natural areas. For $\mathrm{NH}_{4} \mathrm{~N}$, the categories of cultivated irrigated, urban, cultivated dryland, forest and natural areas were found to be influential. For $\mathrm{PO}_{4} \mathrm{P}$, urban areas were found to be most influential, followed by mining and cultivated irrigated. For the most part, these relationships make conceptual sense, as most of these land cover categories are traditionally associated with non-point nutrient inputs, and the predominant association of $\mathrm{PO}_{4} \mathrm{P}$ input with urban areas is also realistic.

\section{Validation of the results of multiple regression}

As illustrated in Fig. 2, the values of $S F_{N}$ generated through multiple regression as compared to $S F_{N}$ generated through model calibration showed discrepancies at lower values of $S F_{N^{\prime}}$ whereas they were generally almost identical at higher values. This perhaps illustrates that at lower non-point inputs, it is difficult to separate the varying impacts on instream water quality, such as possible atmospheric inputs or aquatic faunal and floral inputs of nutrients within the river. In addition, at extremely low $S F_{N}$ values, it is likely that large percentage discrepancies between the two forms of $S F_{N}$ values would be evident.

Figure 3 for C5H056 shows that this discrepancy in $S F_{N}$ can result in large differences in the WQSAM modelling outcomes, and therefore these discrepancies can in fact result in major modelling errors in the estimation of non-point sources. Figure 4 illustrates that at higher $S F_{N}$ values, the multiple regression produces values that are generally in close agreement with those generated through model calibration. These results, shown in Fig. 3 and Fig. 4, point firstly to the inherent problems associated with attempting to quantify relationships between land cover and non-point nutrient inputs using extremely limited observed data: i.e., the lack of suitable sites and observed flow and water quality data, as well as the coarse classification of land cover results and the low statistical power of the regression analyses. Arguably, these results could be used in a water quality model by only applying the relationships to land cover to derive values of $S F_{N}$ in catchments characterised by strong non-point nutrient signatures. Within other catchments, a pragmatic modelling approach may be to apply default low values of $S F_{N}$, after which progressive calibration to any form of observed data can be implemented.

Although there is global recognition that the estimation of non-point inputs of pollutants into rivers is problematic and uncertain, this research can contribute to decreasing this uncertainty. Issues contributing to this uncertainty include the lack of knowledge regarding processes contributing to non-point loads, such as temporal and spatial scales, as well as the pathways of non-point pollutants from the catchment to the river (Munafò et al., 2005). In addition, the input of nonpoint sources of pollutants depends partly on certain random variables such as rainfall, and it is therefore difficult to identify and measure non-point inputs at the source level (Zhang and Wang, 2002). Moreover, there is a high degree of difficulty associated with modelling non-point sources, as the processes driving non-point pollution are complex and have random elements (Han et al., 2011); therefore, models attempting to simulate non-point source inputs would typically require large amounts of observed input data, which in most cases do not exist. Although there are uncertainties associated with the model presented in the current study, the model provides valuable conceptual information on the likely non-point loads contributed from different land covers, and the model is also an improvement on past methods of quantifying non-point source loads, such as export coefficients. The statistical model presented in the current study could potentially be applied separately to the water quality model as a relatively simple method to estimate non-point source loads of nutrients from tributary catchments in South Africa.

\section{Future research}

It is possible that the degree of land cover fragmentation would affect the non-point source inputs of nutrients from a catchment. However, the current study did not assess whether the homogeneity of land cover affects non-point source inputs in the models, and this is left to future research. In addition, the accuracy of the models presented may depend on the position of the study area within a catchment. This is also left to future research. The number of biomes investigated in the current research was limited by available observed water quality data and, depending on whether further data become available, the method could be extended to further biomes. The effect of change in land cover over time on water quality could also be assessed using earlier land cover maps. An additional focus of future research could be to investigate a greater number of riparian (buffer) widths on model accuracy, as the present study investigated one buffer width $(100 \mathrm{~m})$. It is envisaged that these models could be used within calibration of water quality models for an initial parameterisation of non-point source loads or to determine the possible impact on water quality of a change in land cover.

\section{ACKNOWLEDGEMENTS}

This study forms part of a larger study funded by the Water Research Commission (K5/2448).

\section{REFERENCES}

ANBUMOZHI V, RADHAKRISHNAN J and YAMAJI E (2005) Impact of riparian buffer zones on water quality and associated management considerations. Ecol. Eng. 24 517-523. https://doi. org/10.1016/j.ecoleng.2004.01.007

ARNOLD JG, SRINIVASAN R, MUTTIAH RS and WILLIAMS JR (1998) Large area hydrologic modelling and assessment, Part i: model development. J. Am. Water Res. Assoc. 34 73-89. https://doi. org/10.1111/j.1752-1688.1998.tb05961.x

BOWES MJ, NEAL C, JARVIE H.P, SMITH JT and DAVIES HN (2010) Predicting phosphorus concentrations in British rivers resulting from the introduction of improved phosphorus removal from sewage effluent. Sci. Total Environ. 408 4239-4250. https://doi. org/10.1016/j.scitotenv.2010.05.016

DABROWSKI JM, BRUTON S, DENT M, GRAHAM M, HILL T, MURRAY K, RIVERS-MOORE N and VAN DEVENTER H (2013) Linking land use to water quality for effective water resource and ecosystem management. WRC Report No. 1984/1/13. Water Research Commission, Pretoria. 
DABROWSKI JM (2014) Applying SWAT to predict ortho-phosphate loads and trophic status in four reservoirs in the upper Olifants catchment, South Africa. Hydrol. Earth Syst. Sci. 18 2629-2643. https://doi.org/10.5194/hess-18-2629-2014

DWA (Department of Water Affairs, South Africa) (DWA) (2013) Assessing the Impact of Land-based Activities on Water Resources: Final Report for the Automated Land-based Activity Risk Model.

DWS (Department of Water and Sanitation, South Africa (2015) Resource Quality Information Services (RQIS) URL: https:// www.dwa.gov.za/iwqs/report.aspx (Last accessed August 2015). GROBLER DC and SILBERBAUER MJ (1985) The combined effect of geology, phosphate sources and runoff on phosphate export from drainage basins. Water Res. 19 (8) 975-981.

HAN L, HUO F and SUN J (2011) Method for calculating non-point source pollution distribution in plain rivers. Water Sci. Eng. 4 (1) 83-91.

HEATHWAITE AL (2010) Multiple stressors on water availability at global to catchment scales: understanding human impact on nutrient cycles to protect water quality and water availability in the long term. Freshwater Biol. 55 (1) 241-257. https://doi. org/10.1111/j.1365-2427.2009.02368.x

HUGHES DA, HANNART P and WATKINS D (2003) Continuous baseflow separation from time series of daily and monthly streamflow data. Water SA 29 (1) 43-48.

HUGHES DA and SLAUGHTER AR (2016) Disaggregating the components of a monthly water resources system model to daily values for use with a water quality model. Environ. Model. Softw. 80 122-131. https://doi.org/10.1016/j.envsoft.2016.02.028

KAPANGAZIWIRI E, HUGHES DA, TANNER JL and SLAUGHTER AR (2011) Resolving uncertainties in the source of low flows in South African rivers using conceptual and modelling studies. Conceptual and modelling studies of integrated groundwater, surface water and ecological systems. In: Proc. Symposium H01 held during IUGG 2011, July 2011, Melbourne, Australia. IAHS Publ. 345. IAHS, Abingdon, UK.

LOW AB and REBELO AG (eds) (1996) Vegetation of South Africa, Lesotho and Swaziland. DEAT, Pretoria. URL: http://www.ngo. grida.no/soesa/nsoer/Data/vegrsa/vegstart.htm

MAILLARD P and SANTOS NAP (2007) A spatial-statistical approach for modeling the effect of non-point source pollution on different water quality parameters in the Velhas river watershed - Brazil. J. Environ. Manag. 86 (1) 158-170. https://doi.org/10.1016/j. jenvman.2006.12.009

MUNAFÒ M, CECCHI G, BAIOCCO F and MANCINI L (2005) River pollution from non-point sources: a new simplified method of assessment. J. Environ. Manag. 77 93-98. https://doi. org/10.1016/j.jenvman.2005.02.016
NASH JE and SUTCLIFFE JV (1970) River flow forecasting through conceptual models. Part I - a discussion of principles. J. Hydrol. 10 282-290. https://doi.org/10.1016/0022-1694(70)90255-6

PEGRAM GC and GÖRGENS AHM (2001) A guide to non-point source assessment to support water quality management of surface water resources in South Africa. WRC Report No. TT 142/01. Water Research Commission, Pretoria.

PITMAN WV (1973) A mathematical model for generating river flows from meteorological data in South Africa. Report no. 2/73, Hydrological Research Unit, University of the Witwatersrand, Johannesburg, South Africa.

RODRIGUEZ W, AUGUST PV, WANG Y, PAUL JE, GOLD A and RUBINSTEIN N (2007) Empirical relationships between land use/cover and estuarine condition in the Northeastern United States. Landscape Ecol. 22 403-417. https://doi.org/10.1007/ s10980-006-9036-8

SCHULZE RE (1989) (ed.) ACRU: Background Concepts and Theory. ACRU Report No. 36, Dept. Agric. Eng., Univ. of Natal, Pietermaritzburg, RSA.

SCHULZE RE (1995) Hydrology and Agrohydrology: A Text to Accompany the ACRU 3.00 Agrohydrological Modelling System. WRC Report No. TT 95/69. Water Research Commission, Pretoria.

SIMPSON DE and STONE VC (1988) A case study of urban runoff pollution: 1. Data collection, runoff quality and loads. Water SA 14 (2) 229-237.

SLAUGHTER AR and HUGHES DA (2013) A simple model to separately simulate point and diffuse nutrient signatures in stream flow. Hydrol. Res. 44 (3) 538-553. https://doi.org/10.2166/ nh. 2012.213

SLAUGHTER AR and MANTEL SK (2013) A simple and rapid method to relate land cover and river flow to river nutrient concentration. Phys. Chem. Earth 66 131-138. https://doi.org/10.2166/nh.2012.213

SLAUGHTER AR, RETIEF DCH and HUGHES DA (2015) A method to disaggregate monthly flows to daily using daily rainfall observations: model design and testing. Hydrol. Sci. J. 4 (B) 153-171. http://dx.doi.org/10.1080/02626667.2014.993987

VAN DEN BERG EC, PLARRE C, VAN DEN BERG HM and THOMPSON MW (2008) The South African National Land-cover 2000. Report No. GW/A/2008/86. Agricultural Research Council Institute for Soil, Climate and Water, Pretoria.

ZHANG Wand WANG XJ (2002) Modeling for point-non-point source effluent trading: perspective of non-point sources regulation in China. Sci. Total Environ. 292 167-176. https://doi.org/10.1016/ S0048-9697(01)01105-6

ZIMMERMAN JB, MIHELCIC JR and SMITH J (2008) Global stressors on water quality and quantity. Environ. Sci. Technol. 42 (12) 4247-4254. https://doi.org/10.1021/es0871457 